\title{
Indoor Daylighting and Thermal Response of a Passive Solar Building to Selective Components of Solar Radiation
}

\author{
Ochuko Kelvin Overen $^{1, *(\mathbb{D})}$, Edson Leroy Meyer ${ }^{1}(\mathbb{D})$ and Golden Makaka ${ }^{2}$ \\ 1 Fort Hare Institute of Technology, University of Fort Hare, Private Bag X1314, \\ Alice 5700, Eastern Cape, South Africa; emeyer@ufh.ac.za \\ 2 Department of Physics, University of Fort Hare, Private Bag X1314, Alice 5700, Eastern Cape, South Africa; \\ gmakaka@ufh.ac.za \\ * Correspondence: ooveren@ufh.ac.za
}

Citation: Overen, O.K.; Meyer, E.L.; Makaka, G. Indoor Daylighting and Thermal Response of a Passive Solar Building to Selective Components of Solar Radiation. Buildings 2021, 11,

34. https://doi.org/10.3390/ buildings11010034

Received: 11 December 2020

Accepted: 6 January 2021

Published: 19 January 2021

Publisher's Note: MDPI stays neutral with regard to jurisdictional clai$\mathrm{ms}$ in published maps and institutional affiliations.

Copyright: (C) 2021 by the authors. Licensee MDPI, Basel, Switzerland. This article is an open access article distributed under the terms and conditions of the Creative Commons Attribution (CC BY) license (https:// creativecommons.org/licenses/by/ $4.0 /)$.
Abstract: Solar radiation provides the most significant natural energy in buildings for space heating and daylighting. Due to atmospheric interference, solar radiation received at the Earth's surface consists of direct beam and diffuse radiation, where diffuse can be further broken down into longwave and visible radiation. Although each of these components co-occurs, their influence on the indoor visual and thermal conditions of a building differ. This study aims to analyze the influence of the various components of solar radiation on the indoor thermal and daylighting of a passive solar building. Thus, a pyrheliometer, pyranometer, shaded-pyranometer, and pyrgeometer mounted on a SOLYS 2 (Kipp \& Zonen, Delft, Netherlands) dual Axis sun tracker, were used to monitor direct, global horizontal, diffuse and downward longwave radiation, respectively. The seasonal indoor air temperature and relative humidity were measured using an HMP 60 temperature relative humidity probe. A Li-210R photometric sensor was used to monitor the indoor illuminance. The summer and winter indoor air temperature, as well as relative humidity, were found to be influenced by diffuse horizontal and global horizontal irradiance, respectively. In summer, the indoor air temperature response to diffuse horizontal irradiance was $0.7^{\circ} \mathrm{C} / \hbar \mathrm{W} / \mathrm{m}^{2}$ and $1.1^{\circ} \mathrm{C} / \hbar \mathrm{W} / \mathrm{m}^{2}$ to global horizontal irradiance in winter, where $\hbar$ is $99.9 \mathrm{~W} / \mathrm{m}^{2}$. The indoor daylighting which was found to be above the minimum office visual task recommendation in most countries, but within the useful daylight illuminance range was dominated by direct normal irradiance. A response of $260 \mathrm{lux} / \hbar \mathrm{W} / \mathrm{m}^{2}$ was observed. The findings of the study support the strategic locating of the windows in passive solar design. However, the results show that north-facing clerestory windows without shading device could lead to visual discomfort.

Keywords: passive solar design; daylighting; solar heating; indoor comfort; energy efficiency

\section{Introduction}

Globally, the building sector consumes over 30\% of the total final energy, having increased by more than $35 \%$ since 1990 . The building sector is also responsible for $30 \%$ of greenhouse gas (GHG) emission. Additionally, it accounts for half of the world electricity demand, with some region electricity consumption increased by 500\% [1-3]. Space heating and lighting are the primary energy consumers in commercial buildings, with heating accounting for 55 to $60 \%$ and lighting responsible for 27 to $40 \%$ [4]. Building designs have been transformed to reduce the energy consumption in buildings and mitigate the resultant GHG emission. They are designed to harness solar energy to enhance indoor thermal and visible conditions [5]. On the other hand, uncontrollable admittance of solar radiation to the inner space of a building can result in overheating and visual discomfort. Hence, a selective admittance of solar radiation is required for the effective utilization of solar energy in the built environment.

Alteration of atmospheric components such as gas molecules, water vapor, and aerosol split the solar radiation at the Earth's surface into various components [6]. These compo- 
nents are mainly direct and diffuse radiations, with both radiations, further divided into global horizontal radiation, upward (albedo) and downward longwave radiations. Based on the phenomena of occurrence, each of the components of solar radiation transmits to the Earth's surface possesses a different amount of thermal and visible energy.

The concept of selectively admitting solar energy for the indoor environment is as known as passive solar design. Passive solar design adopts various heat movement and strategic locating of the windows to utilize solar radiation for indoor thermal and visual comfort. The positioning of the windows with appropriate shading device also allows selective seasonal sun rays admission, as a means of avoiding overheating during the summer season. The operation of the building windows and the availability of solar radiation play a significant role in achieving an effective design. Therefore, the findings of this study are relevant to builders, glazing (glass) materials manufacturers, and householders. The findings will provide insight into the thermal behaviour and daylighting indoors due to various solar radiation components. At large, orientation, operations, and glazing materials that determine the components solar radiation transmitted indoors can be carefully considered.

This study aims to analyze the influence of direct, global, diffuse, and downward longwave radiations on the thermal condition and the daylight illuminance of a passive solar building office space. In the context of this study, thermal condition is considered as the indoor air temperature and relative humidity.

\section{Components of Solar Radiation}

Solar radiation reaching the Earth's atmosphere is composed of $90 \%$ ultraviolet, $40 \%$ visible, and $50 \%$ infrared; where ultraviolet constitute shortwave radiation and visible and infrared are longwave radiations. Upon arrival, the radiation is subjected to reflection by the outer layer of the Earth's atmosphere; approximately $60 \%$ is transmitted, and the remaining is lost back to space. As a result, the average solar radiation flux density at the Earth's surface, known as solar constant varies from 0 to $1000 \mathrm{~W} / \mathrm{m}^{2}[7,8]$. The solar constant at any given location on the Earth's surface depends on the latitude, season, time of day, and sky formation [9].

The transmitted solar radiation is subjected to further attenuation in the form of absorption. Atmospheric absorption occurs in the form of selective and nonselective absorption [10,11]; where the absorption of the solar radiation spectrum based on wavelength is referred to as selective absorption. Due to such absorption, ultraviolet radiation, with a wavelength lower than $0.3 \mu \mathrm{m}$, is often assumed not to reach the Earth's surface [11]. Additionally, approximately $20 \%$ of near-infrared (shortwave radiation) is absorbed by atmospheric $\mathrm{HO}_{2}$ and $\mathrm{CO}_{2}$ molecules. However, nonselective absorption affects the entire spectrum of solar radiation. Atmospheric absorption is responsible for the higher and less peaky extraterrestrial solar radiation spectrum compared to that at the Earth's surface [12]. Nonselective absorption is mainly as a result of aerosols at different altitude in the atmosphere.

Another form of interference solar radiation undergoes before getting to the Earth's surface is atmospheric scattering. This phenomenon occurs when atmospheric molecules prove unbreakable by the photons of solar radiation, thereby scattering the radiation in all directions. The main components in the atmosphere that constitute scattering are aerosols, $\mathrm{H}_{2} \mathrm{O}, \mathrm{N}_{2}$, and $\mathrm{O}_{2}$ [13]. Scattering affects the visible and infrared spectra only of the solar radiation and depends on their wavelength. Although, it did not influence the wavelength nor energy but alters the direction of propagation.

Vis-à-vis solar radiation observation and measurements, direct or beam radiation is the solar radiation that reaches the Earth's surface without attenuation. Whereby, direct radiation measured on a horizontal plane on the Earth's surface is referred to as direct normal irradiance. On the other hand, diffuse radiation is the scattered solar radiation from the atmosphere to the Earth's surface. The fraction reflected to the atmosphere or space by the Earth's surface (ground and structures) or the outer layers of the atmosphere, 
respectively, are referred to as albedo. The sum of direct and diffuse radiation reaching the Earth's surface, excluding albedo, is called global radiation. Global radiation can be obtained on a vertical and horizontal surface. Measured global radiation on a horizontal plane is called the global horizontal irradiance $[14,15]$. For clarity on the various solar radiation terminology, irradiance is a term used for the instantaneous flux or radiative power of measured solar radiation. Additionally, irradiation is the radiative energy integrated over a specified period, an hour, day, month, or year.

\section{Building and Site Description}

A passive solar building in the SolarWatt Park at the University of Fort Hare, Alice campus was used as a case study. Alice is in latitude $32.8^{\circ}$ south and longitude $26.8^{\circ}$ east at an altitude of $540 \mathrm{~m}$ in the Eastern Cape of South Africa. The local climatic is characterized by an average dry bulb temperature of $29{ }^{\circ} \mathrm{C}$ in summer and $15^{\circ} \mathrm{C}$ in winter [16]. The average solar radiation experienced in the summer is $606.06 \mathrm{~W} / \mathrm{m}^{2}$ and $346.17 \mathrm{~W} / \mathrm{m}^{2}$ in winter [17]. A photo of the passive solar building used is shown in Figure 1.

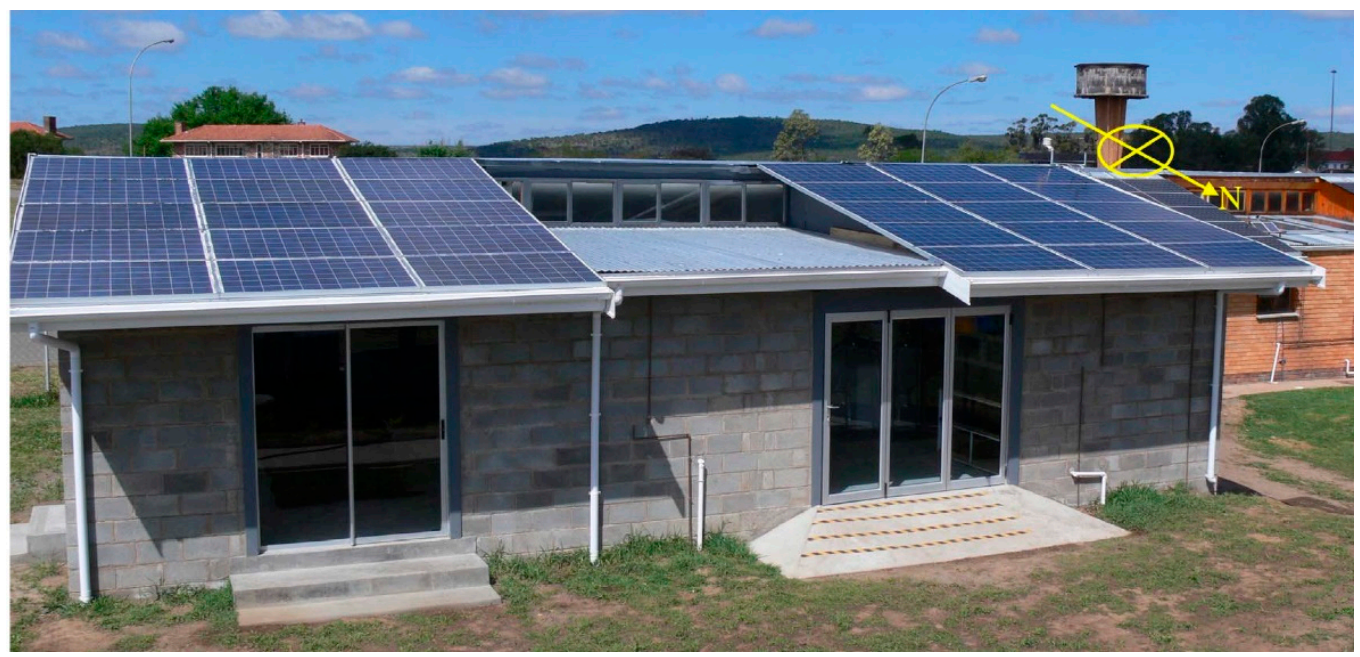

Figure 1. Passive solar building in SolarWatt Park at the University of Fort Hare in Alice.

The building is orientated approximately $15^{\circ}$ east of north with a total floor area of $10 \mathrm{~m} \times 8 \mathrm{~m}\left(80 \mathrm{~m}^{2}\right)$. The floor arrangement of the building is made up of a conference room at the east wing of the building, office space and indoor solar simulator laboratory occupying the west wing. The conference room and office space stretch from the north to the south elevation of the building. The two-sash glass sliding north-facing door in the conference room admit the low angle sun's rays to the north floor area, as well as the three-sash glass folding-door in the office space. Likewise, the clerestory windows are used to channel solar radiation to the southern floor area of the conference room and office space. Hence, passive solar space heating can be achieved in the winter season and enhanced daylighting. However, the $1 \mathrm{~m}$ eaves prevent the high angle sun rays in the summer season. The results and discussions were based on the thermal and daylighting response of the office space.

\section{Methodology}

\subsection{Solar Monitoring System}

A solar monitoring station in SolarWatt Park was used to measure the various solar radiation components. As discussed in Section 2, the components of solar radiation measured include direct normal irradiance (DNI), diffuse horizontal irradiance (DHI), global horizontal irradiance (GHI) and downward longwave irradiance $\left(\mathrm{L}_{\mathrm{d}}\right)$. To simultaneously monitor the aforesaid solar radiation components, SOLYS Gear Drive (SGD) sun tracker 
was used. A photo of the setup SGD sun tracker and various radiometers are shown in Figure 2 .

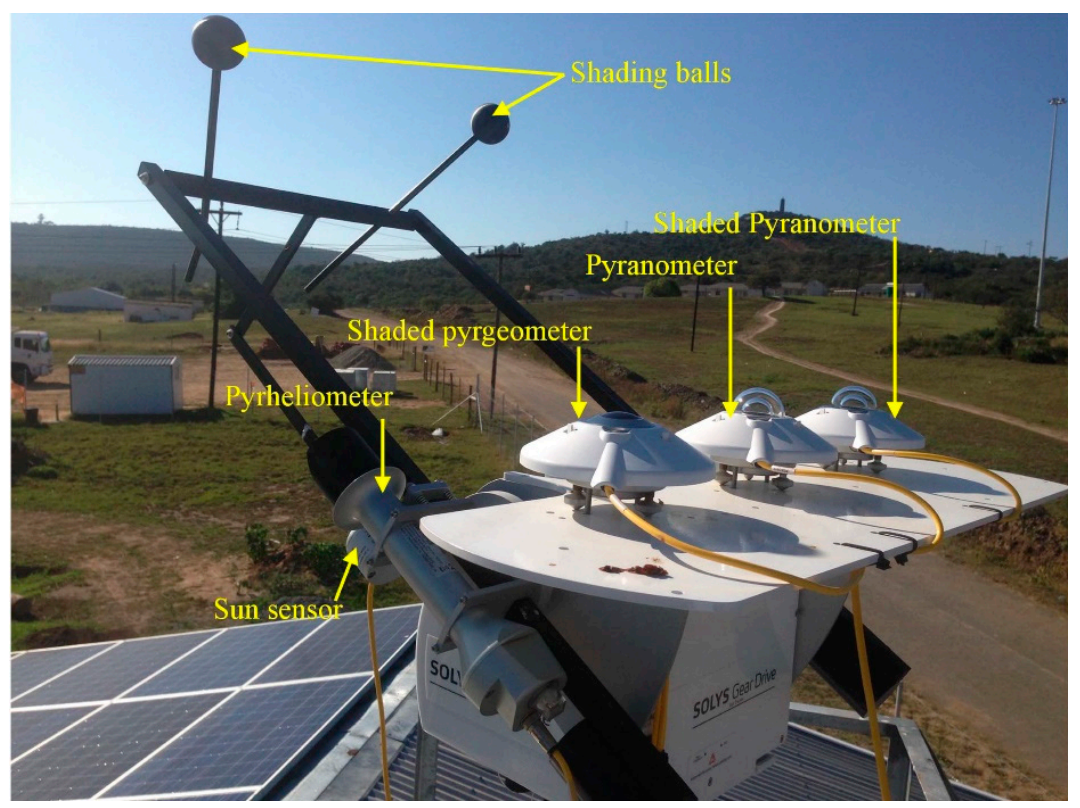

Figure 2. SOLY Gear Drive dual-axis sun tracker measuring the selected components of solar radiation in SolarWatt Park, Alice.

In Figure 2, the SGD sun tracker comprises of a CHP 1 pyrheliometer, CGR4 pyrgeometer and two sets of CMP10 pyranometers. The SGD sun tracker was designed to offset the diurnal and seasonal movement of the Earth [18]; thereby, continually pointing the payload toward the sun. The motion of the payload is aided by a sun sensor installed in the system. The sun sensor identifies the area in the sky with maximum solar intensity and directs the payload to that region. Besides the sun sensors, the tracker uses the geographic coordinate and local time obtained by the integrated GPS antenna to track the daily movement of the sun. Thus, the pyrheliometer which measures the DNI is continually pointed towards the sun's disc during the day.

On the other hand, the pyrgeometer and two pyranometers located on the platform of the sun tracker, move about their axis. The pyrgeometer is used to measure the downward reemitted (infrared) radiation of the atmosphere, which is referred to as downward longwave $\left(\mathrm{L}_{\mathrm{d}}\right)$ radiation. The pyranometer at the extreme right of the platform, monitors diffused solar radiation. Hence, the shading assembly uses the shading balls to shield the shaded pyrgeometer and pyranometer from direct solar radiation. The pyrgeometer was shaded to avoid the build-up of heat by shortwave radiation. The unshaded pyranometer in the middle of the platform measures the combine direct and diffuse radiation also known as GHI.

Like most Kipp Zonen CMP series, the abovementioned radiometers use a passive thermal sensing element called a thermopile to detect irradiance. The thermopile consists of thermocouple junction pairs connected in series. The measurement (hot) junction of one of the thermocouples absorbed thermal radiation, increasing its temperature. The difference between the measurement and a fixed temperature reference (cold) junction produces a voltage directly proportional to the differential temperature created. This concept is known as the thermoelectric effect [19]. Although thermopiles' construction differs and varies with the model, the principle of operation is the same. However, the sensitivity of a given radiometer thermopile depends on its physical properties [20]. The specification of the radiometers used in the study are summarised in Table 1. 
Table 1. Specification of the radiometers.

\begin{tabular}{cccc}
\hline & \multicolumn{3}{c}{ Specification } \\
\cline { 2 - 4 } Radiometer & Spectral Range $(\mu \mathrm{m})$ & $\begin{array}{c}\text { Sensitivity } \\
\left(\mu \mathrm{V} / \mathrm{W} / \mathbf{m}^{2}\right)\end{array}$ & Response Time (s) \\
\hline Pyheliometer & 0.2 to 4 & 7 to 14 & $<5$ \\
Pyrgeometer & 4.5 to 42 & 5 to 10 & $<18$ \\
Pyranometer & 0.3 to 2.8 & 7 to 14 & $<5$ \\
\hline
\end{tabular}

The response time in Table 1 refers to the delay taken by the individual radiometer to respond to incident radiation. Additionally, the said response time is the time taken for a particular radiometer to deliver $95 \%$ of its measurement following a step-change in irradiance.

\subsection{Thermal Monitoring}

The indoor air temperature and relative humidity of the office space were measured using HMP 60 temperature relative humidity probes. Figure 3 shows the inner space of the office and a setup outdoor weather station. As shown in Figure 3a, the HMP60 probe was suspended at a height of $1.8 \mathrm{~m}$. This is to ensure that the temperature felt by the occupants is measured. Additionally, at that height, the probe was not interfering with the occupant's activities. The ambient air temperature and relative humidity of the building were also monitored with a similar HMP 60 probe. Although, the ambient HMP 60 temperature relative humidity probe was housed in a 6-plate natural aspirated radiation shield, as shown in Figure $3 b$.

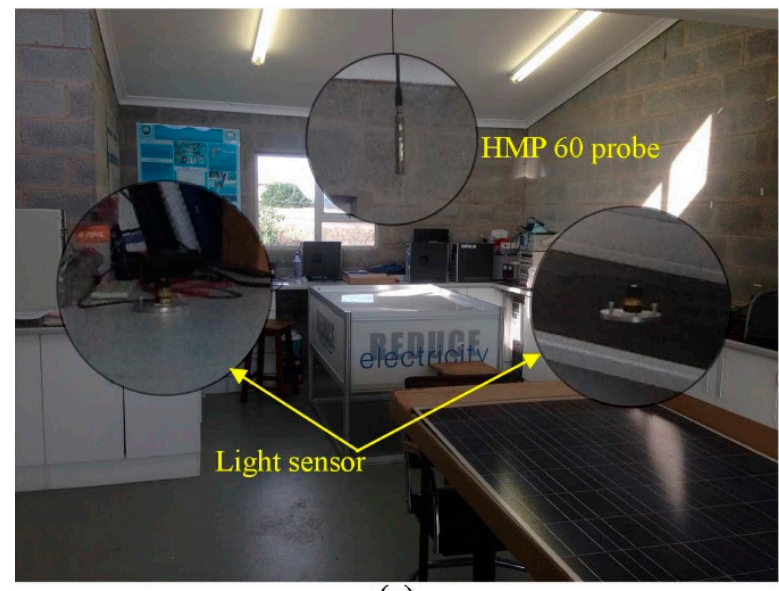

(a)

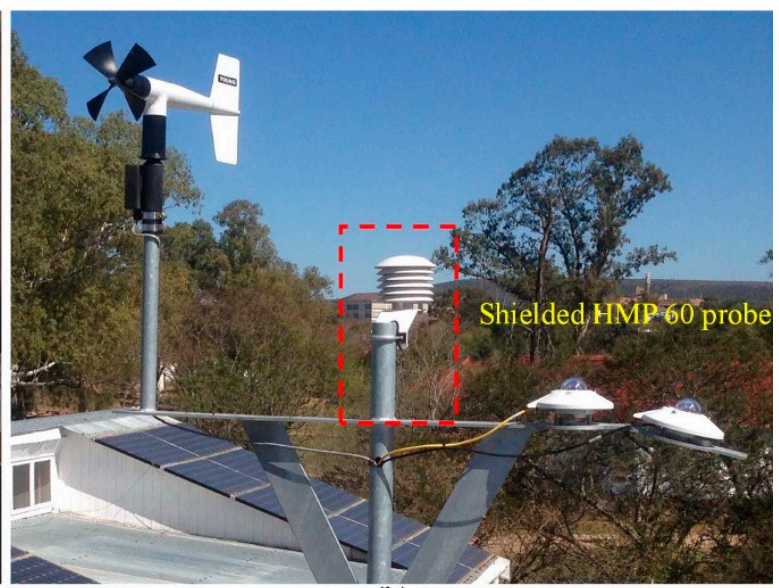

(b)

Figure 3. (a) Inner space of the office indicating the HMP60 temperature and relative humidity probe and photometer sensor; (b) a setup outdoor weather station indicating the shield HMP60 temperature and relative humidity probe.

The white painted radiation shield reflects solar radiation from the HMP60 probe. Meanwhile, the louvre allows natural free flow of air through the shield, keeping the probe close as possible to the ambient air temperature (eliminating solar effect) and water vapor [21]. The HMP60 probe uses a platinum resistance temperature (PRT) detector to measure air temperature. The PRT detector sensed temperature by measuring the electrical resistance of a noble metal such as platinum. The resistance of the platinum wire is measured, passing DC through it, and obtaining its voltage. The measured voltage is converted into temperature using a calibrated equation [22,23]. The measurement specifications of HMP 60 probe temperature and relative humidity sensor are given in Table 2 [24]. 
Table 2. HPM 60 temperature and relative humidity sensors specification.

\begin{tabular}{cccc}
\hline Parameters & \multicolumn{2}{c}{ Measurement Range } & Accuracy ( \pm ) \\
\hline Temperature $\left({ }^{\circ} \mathrm{C}\right)$ & \multicolumn{2}{c}{$-40-60$} & 0.6 \\
\hline \multirow{3}{*}{ Relative humidity $(\%)$} & at $0-40{ }^{\circ} \mathrm{C}$ & $0-90$ & 3 \\
& & $90-100$ & 5 \\
\cline { 2 - 4 } & at $0-40{ }^{\circ} \mathrm{C}$ & $0-90$ & 5 \\
& and $+40-60^{\circ} \mathrm{C}$ & $90-100$ & 7 \\
\hline
\end{tabular}

Also, air relative humidity is measured by a capacitive relative humidity sensor. This sensor is a capacitor of hygroscopic dielectric material between a pair of the electrode. At equilibrium conditions, the amount of moisture present in the hygroscopic material depends on both ambient air temperature and water vapor pressure. Given that relative humidity is also a function of air temperature and water vapor pressure, a relationship exists between relative humidity, the moisture present in the sensor, and sensor capacitance. This relationship is the principle of operation of the capacitive humidity instrument $[25,26]$.

\subsection{Illuminance Measurement}

The illuminance level of the office space was measured by two sets of LI-210R cosine correction photometric sensors. The LI-210R photometric sensor (Li-Cor, Lincoln, Nebraska, United States of America) uses a precision filtered silicon photodiode (blue enhanced) that is sensitive to visible light to measure the illuminance level of a given space. The silicon photodiode is mounted on a cosine-corrected head. In measuring radiation, cosinecorrected sensors operate base on the principle of Lambert's cosine law. The law states that the radiation observed from an ideal diffusely reflecting surface is directly proportional to the cosine of the angle $\theta$ between an observer's line of sight and the surface normal. The correction (Lambert surface) provide a uniform diffusion of the incident radiation. Thus, irradiance is the same in all direction from which it can be measured. The LI-210R sensor has a sensitivity of $30 \mu \mathrm{A}$ per $100 \mathrm{klux}$ and a response time of $<1 \mu \mathrm{s}$ [27].

The light perceived by an occupant sitting at the desk was the target of the measurement. To this effect, one photometric sensor was placed on the left (east side) and right (west side) desk array, as shown in Figure 3a. The sensors were located in an open space, free of light rays' obstacle to avoid shading. Additionally, the occupants (students and technicians), were requested not to tamper with the sensor and obstruct light rays around the measurement area.

\section{Results and Discussions}

During the period of this research, the building was a working place for five students and two technical staff members, while other students and staff members visited periodically. Hence, the office space entrance (north facing) door was always open during operation hours, which was observed to be 8:00 to 17:00 weekdays. The conference room was closed, as it was occasionally used. The students often used the east side of the office space for their research activities while the west side served as a working area for the technicians. It should be mentioned that during the research period, no mechanical cooling or heating system was used in the building.

\subsection{Analysis of Solar Radiation Components}

The solar radiation components were measured concurrently with the indoor thermal conditions and illuminance level of the building from April to December 2017. Figure 4 shows the measured solar irradiance components during the entire monitoring period. Due to the clustering appearance of the measured solar irradiance, which impedes the distribution pattern visibility, the 125 period moving average of the parameters was presented in Figure 4. 


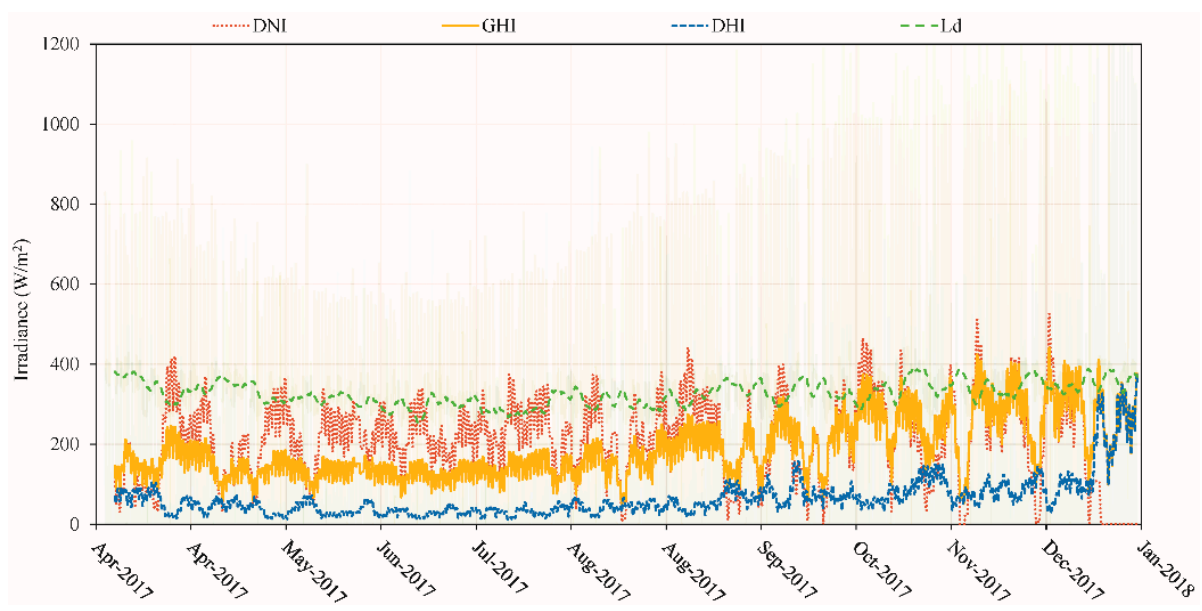

Figure 4. Various components of the solar radiation distribution.

As stated earlier, the reemitted solar radiation from atmospheric to the Earth's surface is known as downward longwave $\left(\mathrm{L}_{\mathrm{d}}\right)$ radiation. This radiation is essential in regulating the temperature (warming) of the Earth [28]. Research studies show that the average $\mathrm{L}_{\mathrm{d}}$ radiation at the Earth's surface ranges from 343.5 to $420 \mathrm{~W} / \mathrm{m}^{2}$ [29-31]. The measured $L_{d}$ radiation in Figure 3 was not far from literature findings with a range of 235.8 to $443.2 \mathrm{~W} / \mathrm{m}^{2}$. Assuming GHI $\geq 1 \mathrm{~W} / \mathrm{m}^{2}$ to be periods that the sun is present, and $\mathrm{L}_{\mathrm{d}} \geq 400 \mathrm{~W} / \mathrm{m}^{2}$ are maximum $\mathrm{L}_{\mathrm{d}}$ irradiance. In the presence of the sun, $78 \%$ of maximum $\mathrm{L}_{\mathrm{d}}$ irradiance was observed in the period with minimum DNI $\left(<10 \mathrm{~W} / \mathrm{m}^{2}\right)$ and the average DHI was $222.9 \mathrm{~W} / \mathrm{m}^{2}$. The above scenario tends to agree with theory [32,33], an increase in the atmosphere content such as water vapor, dust particles, and gas molecules increase the absorption of DNI and the re-emission of $\mathrm{L}_{\mathrm{d}}$ radiation. This behaviour results in a minimal DNI and higher DHI at the Earth's surface. From Figure 3, it was also observed that between June and August, as well as in May; the beginning of the winter season, GHI was lower than DNI. Over the four months, an average GHI of $139 \mathrm{~W} / \mathrm{m}^{2}$ and $215.9 \mathrm{~W} / \mathrm{m}^{2}$ DNI was obtained. An opposite pattern was observed as the summer season approaches, moving from September to December. In the summer season, the average GHI and DNI were 245.2 and $208.8 \mathrm{~W} / \mathrm{m}^{2}$, respectively. The DHI was observed to follow the same trend with an average of $37.3 \mathrm{~W} / \mathrm{m}^{2}$ in summer and $87.6 \mathrm{~W} / \mathrm{m}^{2}$ in winter. It is often assumed that the winter season presents a more transparent atmosphere as compared to the summer season [34,35], the findings obtained from Figure 4 tend to support the assumption. To further analyze the seasonal distribution of the solar radiation components concerning atmospheric conditions, selected clear sky and overcast days in summer and winter season are given in Figure 5.

In the context of this study, the sky classifications were based on the shape of the measured solar radiation (GHI) distribution. A regularly distributed irradiance profile serves as a clear sky day while an irregular irradiance distribution was used as an overcast sky day. Thus, 12 and 13 November 2017, respectively, represents the typical summer clear sky and overcast days. Typical winter clear sky day was represented by 29 July 2017, and 30 July 2017 serves as an overcast winter day. Theoretically, a clear sky is characterized by high atmosphere transparency (clearness index; $\mathrm{K}_{\mathrm{T}} \sim 0.80$ ) induced by reduced air mass, aerosols, water vapor, and gas molecules in the atmosphere. Alternatively, a dense sky with $\mathrm{K}_{\mathrm{T}} \leq 0.17$ is a distinctive property of an overcast sky. In both sky formations, a higher $\mathrm{K}_{\mathrm{T}}$ value implies a more transparent atmosphere [36-39]. The former sky condition delivers maximum DNI and minimum DHI, a reverse scenario is a case for the latter. As seen in Figure 5, the measured components of solar radiation agree with theory. On a clear sky day, the peak GHI was higher than that of the DNI by $59 \mathrm{~W} / \mathrm{m}^{2}$ in summer and lesser by $179.5 \mathrm{~W} / \mathrm{m}^{2}$ in winter. In both seasons, in the absence of DNI due to overcast sky condition, the DHI was equal to the GHI. Irrespective of the seasons, a relatively equal $\mathrm{L}_{\mathrm{d}}$ irradiance 
was observed. Moreover, the maximum $\mathrm{L}_{\mathrm{d}}$ irradiance was seen in overcast summer day; higher by an average of $33.0 \mathrm{~W} / \mathrm{m}^{2}$. Winter clear sky day had the least $\mathrm{L}_{\mathrm{d}}$ irradiance, lower by an average of $30.9 \mathrm{~W} / \mathrm{m}^{2}$.
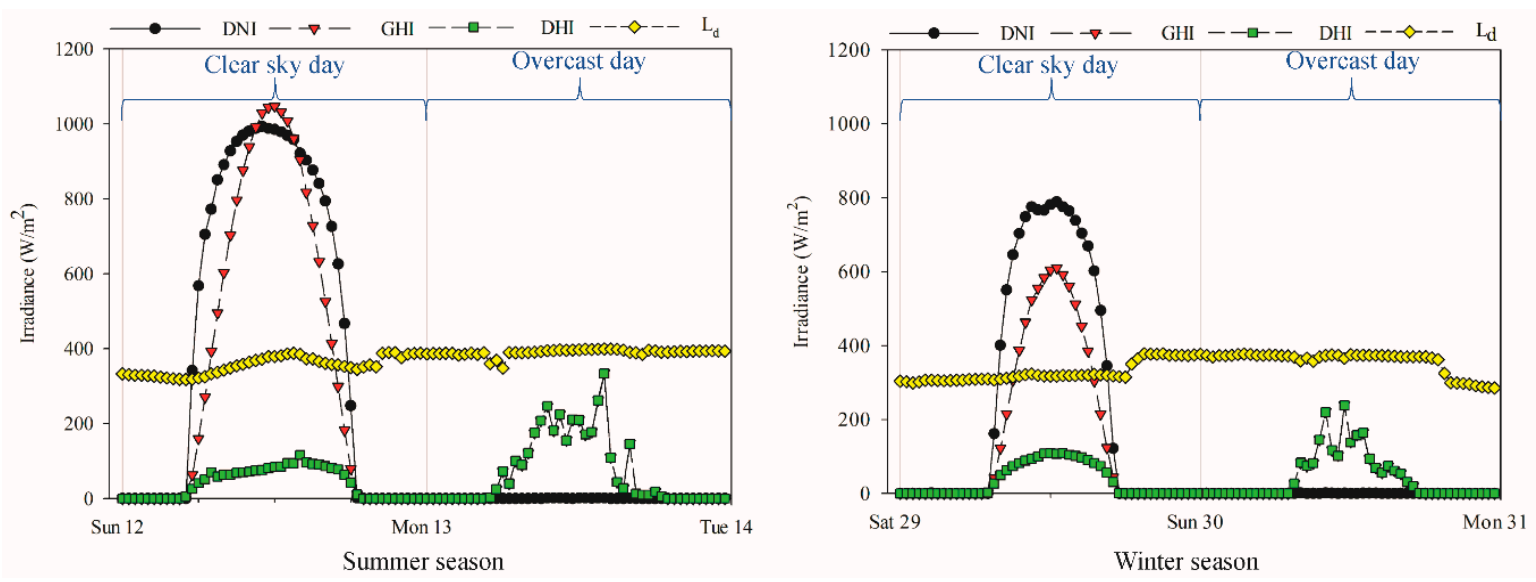

Figure 5. Typical seasonal clear sky and overcast solar radiation components distribution.

\subsection{Thermal Response Analysis}

The outdoor air temperature and relative humidity of the building during the research period as well as their corresponding indoor air temperature and relative humidity are given in Figure 6. Additionally, to enhance the visibility of the temperature and relative humidity distribution, the 125 moving average of both parameters were obtained. For the entire period, the average outdoor air temperature and relative humidity were $15^{\circ} \mathrm{C}$ and $66 \%$, respectively. The corresponding average indoor air temperature was found to be $7{ }^{\circ} \mathrm{C}$ higher, and the relative humidity was $26 \%$ lower. The outdoor air temperature as indicated in Section 4, does not include the effect of solar radiation, as well as the indoor air temperature. The chilling effect of the wind, therefore, result in relatively lower outdoor air temperature. According to the South Africa Bureau of Standards [40], the average indoor air temperature and relative humidity were within the thermal comfort zone; given a range of 20 to $24{ }^{\circ} \mathrm{C}$ and 30 to $60 \%$ for recommended indoor air temperature and relative humidity, respectively.

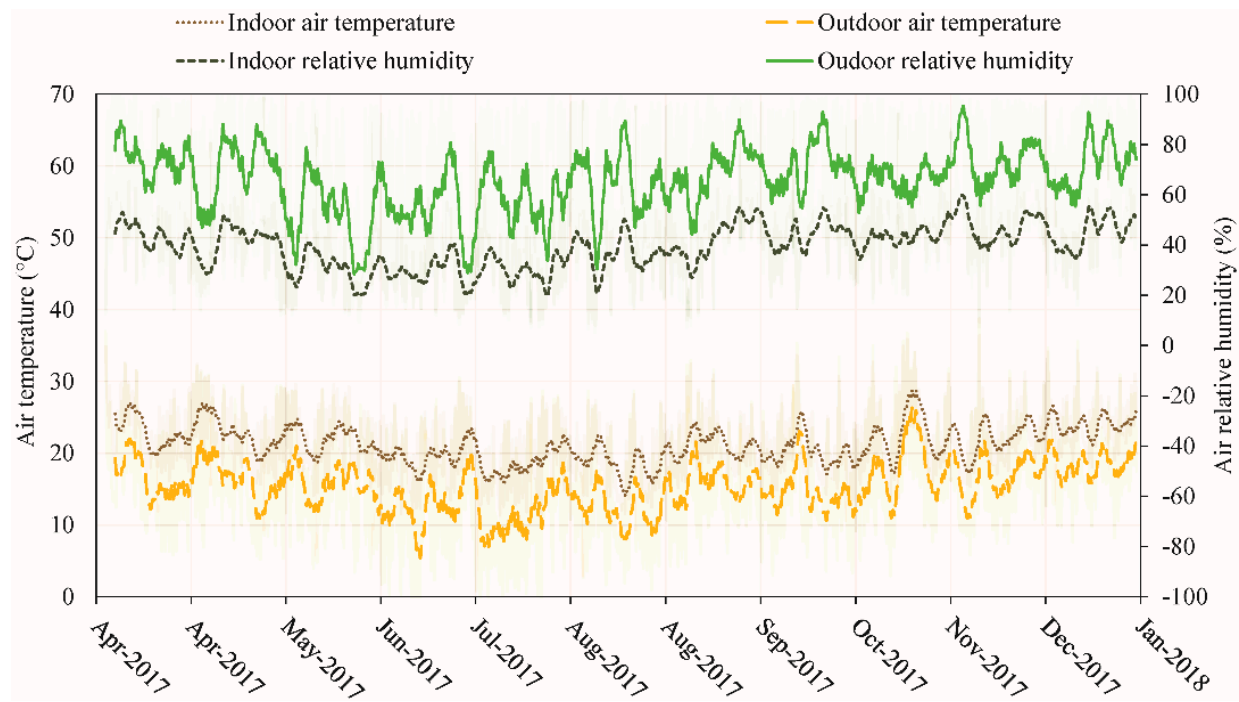

Figure 6. Average indoor and outdoor air temperature and relative humidity distribution. 
A total of 8609 data entries was obtained for summer and 4365 in winter. The measured components of solar radiation were further divided into 16 classes of $\hbar$ width, where $\hbar$ is $99.99 \mathrm{~W} / \mathrm{m}^{2}$. The average air temperature and relative humidity of the indoor and ambient air of the building in each of the solar radiation component classes were also obtained. The seasonal response of the indoor and outdoor air temperature and relative humidity to the various components of solar radiation are given in Figures 7 and 8.

In both Figures 7 and 8 , class 0 to $99.99 \mathrm{~W} / \mathrm{m}^{2}$ was the most occurrence with an average of $72 \%$ : excluding downward longwave radiation. In the class of 0 to $99.99 \mathrm{~W} / \mathrm{m}^{2}$, approximately $80 \%$ of the data were measured during the absence of the sun, i.e., GHI $<1$. The average resultant indoor air temperature and relative humidity during the specified period were, respectively, $23{ }^{\circ} \mathrm{C}$ and $44 \%$ in summer, and $18{ }^{\circ} \mathrm{C}$ and $33 \%$ in winter. Additionally, an increase in occurrence was observed as the DNI increases. However, a relatively constant indoor and outdoor temperature with a swing of $3{ }^{\circ} \mathrm{C}$ and $8{ }^{\circ} \mathrm{C}$, respectively, in both seasons were observed. A different behaviour was seen in the GHI and DHI distribution, the occurrence of the radiation decreases as the irradiance increase in both seasons. Compare to DNI distribution; GHI distribution resulted in a vigorous temperature swing of $5{ }^{\circ} \mathrm{C}$ indoors and $10{ }^{\circ} \mathrm{C}$ outdoors in summer and winter. The indoor and outdoor air temperature swing due to the $\mathrm{DHI}$ distribution in summer was $5^{\circ} \mathrm{C}$ and $9{ }^{\circ} \mathrm{C}$, respectively. In winter, the air temperature in both environments this were reduced by $3{ }^{\circ} \mathrm{C}$. $\mathrm{L}_{\mathrm{d}}$ occurred in only three classes and was never observed in the class of 0 to $99.99 \mathrm{~W} / \mathrm{m}^{2}$.
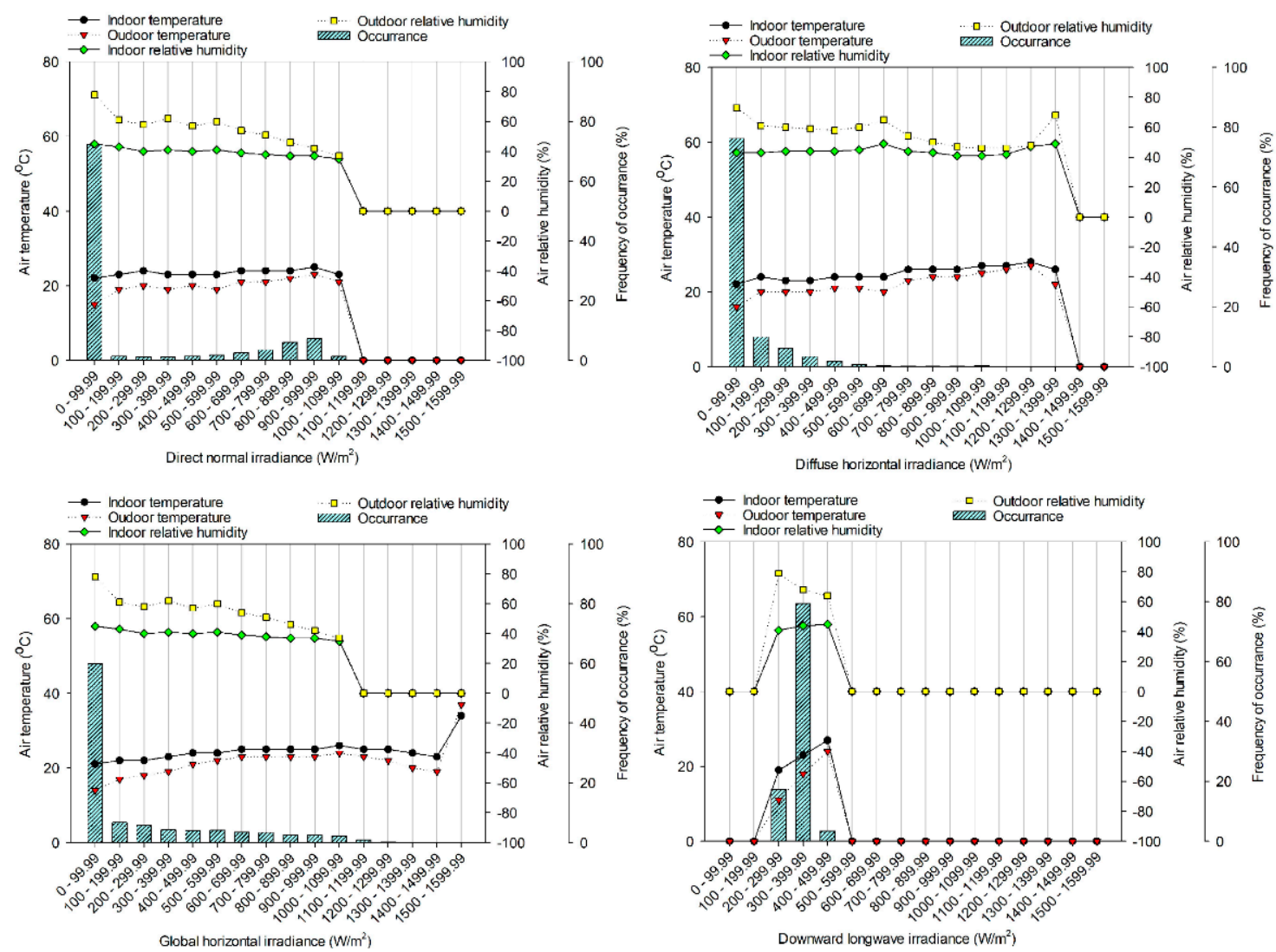

Figure 7. Indoor and outdoor thermal response to various components of solar radiation in summer. 

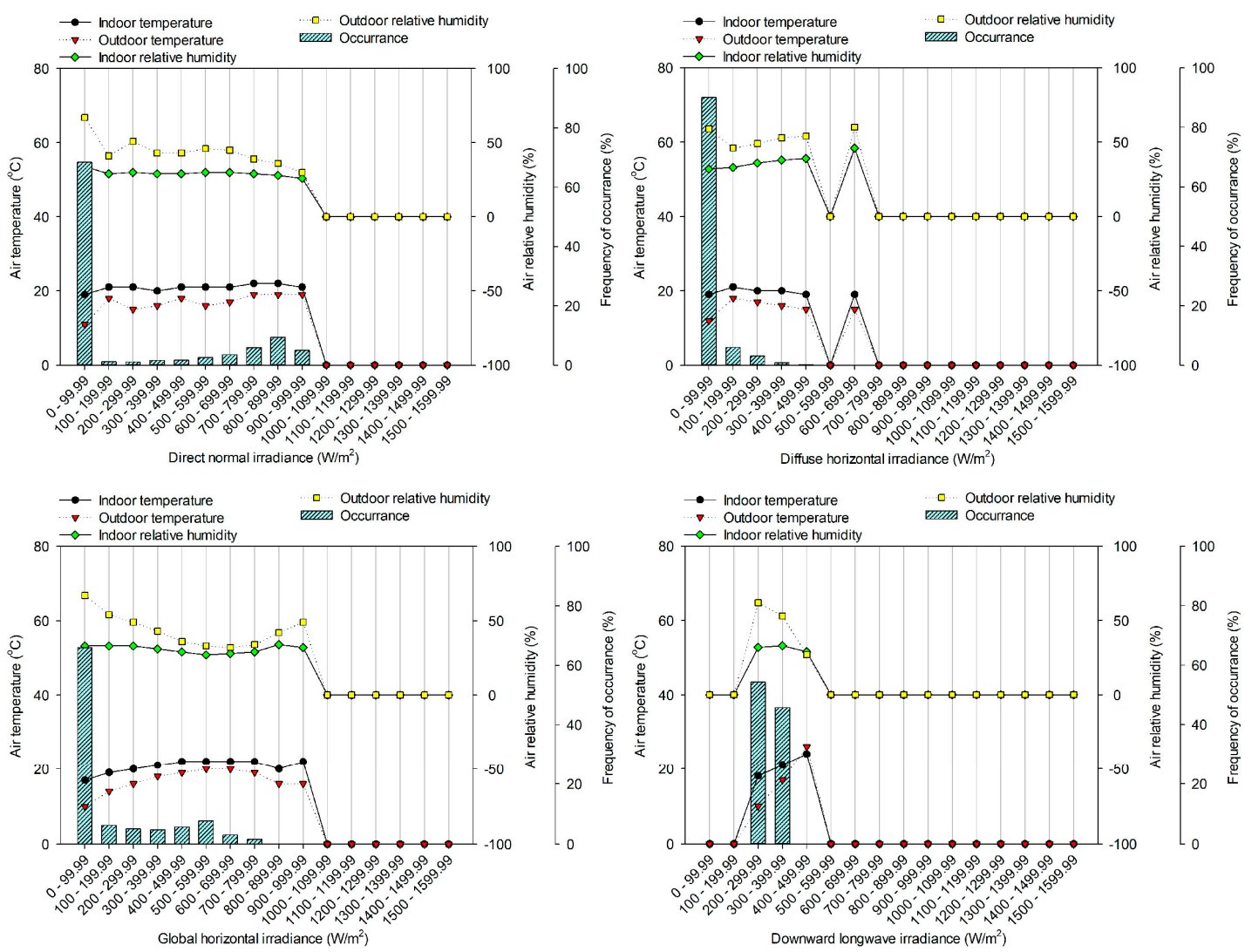

Figure 8. Indoor and outdoor thermal response to various components of solar radiation in winter.

However, the $L_{d}$ irradiance distribution resulted in the maximum indoor air temperature swing of 8 and $6{ }^{\circ} \mathrm{C}$ outdoors. The response of the indoor and outdoor air temperature and relative humidity to the components of solar radiation is summarised in Table 3 .

Table 3. Thermal response of the passive solar building to solar radiation components.

\begin{tabular}{cccccc}
\hline \multirow{2}{*}{ Season } & $\begin{array}{c}\text { Solar } \\
\text { Radiation } \\
\text { Component }\end{array}$ & $\begin{array}{c}\text { Indoor Thermal Response } \\
\text { Temperature } \\
\left({ }^{\circ} \mathbf{C} / \hbar \mathbf{W} / \mathbf{m}^{\mathbf{2}}\right)\end{array}$ & $\begin{array}{c}\text { Relative } \\
\text { Humidity } \\
\left(\mathbf{\%} / \hbar \mathbf{W} / \mathbf{m}^{\mathbf{2}}\right)\end{array}$ & $\begin{array}{c}\text { Outdoor Thermal Response } \\
\left({ }^{\circ} \mathbf{C} / \hbar \mathbf{W} / \mathbf{m}^{\mathbf{2}}\right)\end{array}$ & $\begin{array}{c}\text { Relative } \\
\text { Humidity } \\
\left(\mathbf{\%} / \hbar \mathbf{W} / \mathbf{m}^{\mathbf{2}}\right)\end{array}$ \\
\hline \multirow{5}{*}{ Summer } & $\mathrm{DNI}$ & 0.5 & 1.0 & 1.0 & 3.9 \\
& $\mathrm{DHI}$ & 0.7 & 1.6 & 1.3 & 4.5 \\
& $\mathrm{GHI}$ & 0.6 & 1.0 & 1.1 & 4.3 \\
& $\mathrm{~L}_{\mathrm{d}}$ & 0.6 & 0.3 & 0.9 & 1.1 \\
\hline \multirow{5}{*}{ Winter } & $\mathrm{DNI}$ & 0.4 & 0.9 & 1.3 & 4.5 \\
& $\mathrm{DHI}$ & 0.3 & 0.5 & 0.6 & 1.5 \\
& $\mathrm{GHI}$ & 0.6 & 1.1 & 1.0 & 3.7 \\
& $\mathrm{~L}_{\mathrm{d}}$ & 0.4 & 0.4 & 1.1 & 2.5 \\
\hline
\end{tabular}

The findings in Table 3 is attributed to the method adopted in measuring the air temperature and relative humidity. As stated earlier, the effect of solar radiation was excluded from both parameters. Hence, DNI had the least influence on the indoor air temperature and relative humidity irrespective of the seasons. The DHI and GHI were however found to be the most influential in the summer and winter seasons, respectively. As per the design of the building discussed in Section 3, the overhanging roof used as a shading device prevents summer high angle direct sun rays from entering the inner space of the building. Therefore, DHI due to scattered sun rays dominates the inner space in 
summer. The relatively higher transparent atmosphere, which is typically experienced in winter, results in the lower influence of the DHI on the air temperature and relative humidity in the season. Additionally, in summer, the design of the building was meant to admit direct sun rays. It should be noted that the GHI class of $1500-1599.99 \mathrm{~W} / \mathrm{m}^{2}$ with a resultant indoor air temperature of $34^{\circ} \mathrm{C}$ and $37^{\circ} \mathrm{C}$ outdoor, as well as an occurrence of $0.01 \%$ was not included in the computed thermal response in Table 3. Due to the limited occurrence frequency and wide temperature and relative humidity margin obtain from the specified GHI class, the class was considered as an outliner.

Furthermore, the influence of sky formation on the thermal behaviour of the building was also analyzed. Hence, the corresponding indoor and outdoor air temperature and relative humidity of the selected seasonal sky formation days were used for the said analysis. Figure 9 shows the seasonal indoor and outdoor air temperature and relative humidity distribution under various sky formation.
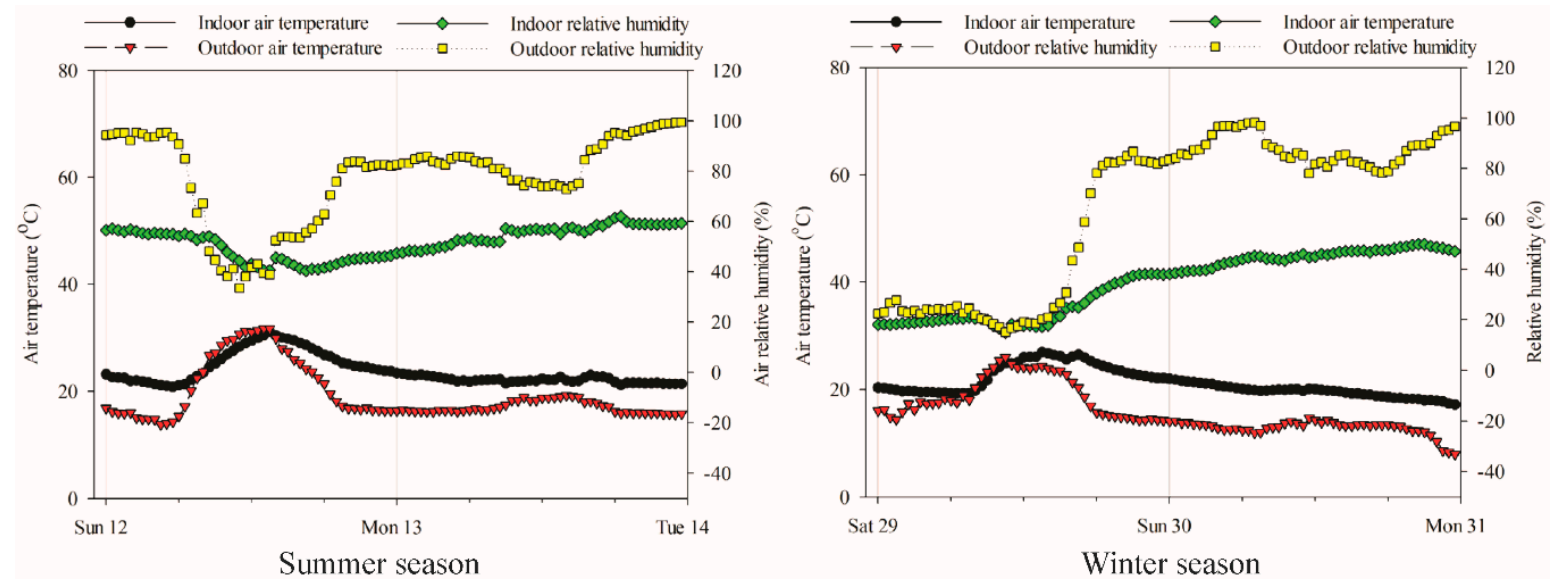

Figure 9. Seasonal air temperature and relative humidity response of the passive solar building on a typical clear sky and overcast day.

In Figure 9, overcast days resulted in a relatively constant indoor and outdoor air temperature. In both seasons, the average indoor and outdoor air temperature change rate was approximately $0.1{ }^{\circ} \mathrm{C} / \mathrm{h}$. Regarding the indoor and outdoor relative humidity, the change rates were 0.4 and $0.6 \% / \mathrm{h}$, respectively, in summer. The same trend was observed in the winter season; the outdoor relative humidity change rate was higher by $0.6 \% / \mathrm{h}$ than the indoor relative humidity. Clear sky days, however, generated a more dynamic air temperature distribution, resulting in an average change rate of $0.2^{\circ} \mathrm{C} / \mathrm{h}$ indoors and $0.4{ }^{\circ} \mathrm{C} / \mathrm{h}$ outdoors in both seasons. The corresponding average indoor relative humidity change rate was $0.4 \% / \mathrm{h}$ and $1.4 \% / \mathrm{h}$. Nonetheless, the seasons were observed to be the most influencing factor of the indoor air temperature and relative humidity distribution within the thermal comfort zone rather than the sky formation. In the summer overcast day, the average indoor air temperature and relative humidity were in the thermal comfort zone by $2{ }^{\circ} \mathrm{C}$ and $25 \%$, respectively. The indoor air temperature in winter was however in the thermal comfort zone by an average of $3{ }^{\circ} \mathrm{C}$ on the clear sky day. Although, the corresponding indoor air relative humidity was below the thermal comfort zone by an average of $6 \%$.

\subsection{Indoor Illuminance Response}

The indoor illuminance, which comprises artificial (electric) and natural (daylighting) lighting was monitored from April to May 2017. As indicated earlier, the illuminance measurement focuses on the light perceived by an occupant at the left (east side) and right (west side) desk array in the office space. The office space (indoor) illuminance is, therefore, the average illuminance measured at both desk array. The illuminance at both desk array and the average indoor illuminance is given in Figure 10. 


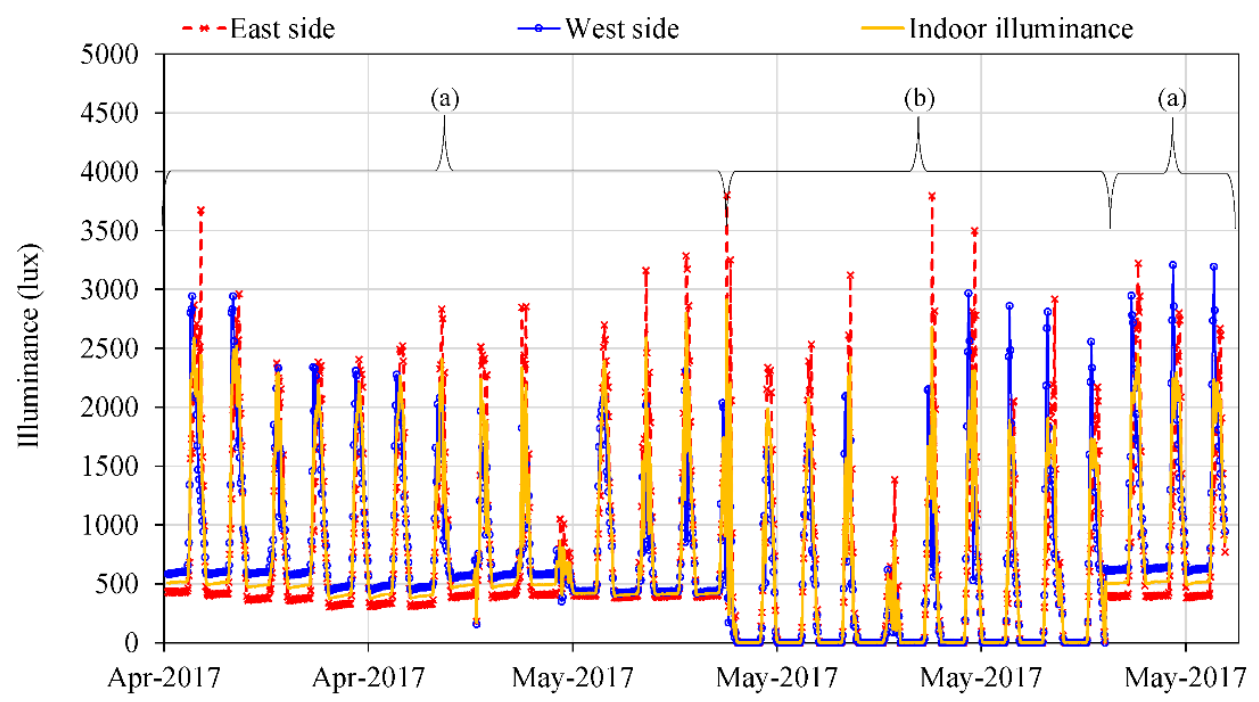

Figure 10. Indoor illuminance distribution of the passive solar building.

A set of four cool white, fluorescent fixtures are the electric lighting used to illuminate the office space alongside the daylighting. Each of the fixtures consists of two $58 \mathrm{~W}$ lamp. Thus, in Figure 10, region (a) indicates the period with all lamps on, and region (b) is the period with all lamps off. In the absence of the sun, the average indoor illuminance with all lamps switched off was 31 lux, and 460 lux with all lamp switched on. The indoor daylight illuminance which takes into consideration only the period that the sun was present (07:00-17:00) and all lamps switched off was 850 lux. As indicated in Figure 10, a combination of daylighting and electrical lights are used in most instances, during such period, the average illuminance of the office space was found to be 1300 lux.

Also, the influence of sky formation on the indoor daylighting was analyzed taking 29 April and 4 May as a clear sky and overcast day, respectively. The identified clear sky day had a regular GHI distribution with a maximum irradiance of $696.0 \mathrm{~W} / \mathrm{m}^{2}$. Contrarily, an irregular GHI distribution with a maximum below $300 \mathrm{~W} / \mathrm{m}^{2}$, was observed in the overcast day. Figure 11 shows the GHI and indoor illuminance of the building on the selected clear sky and overcast days.
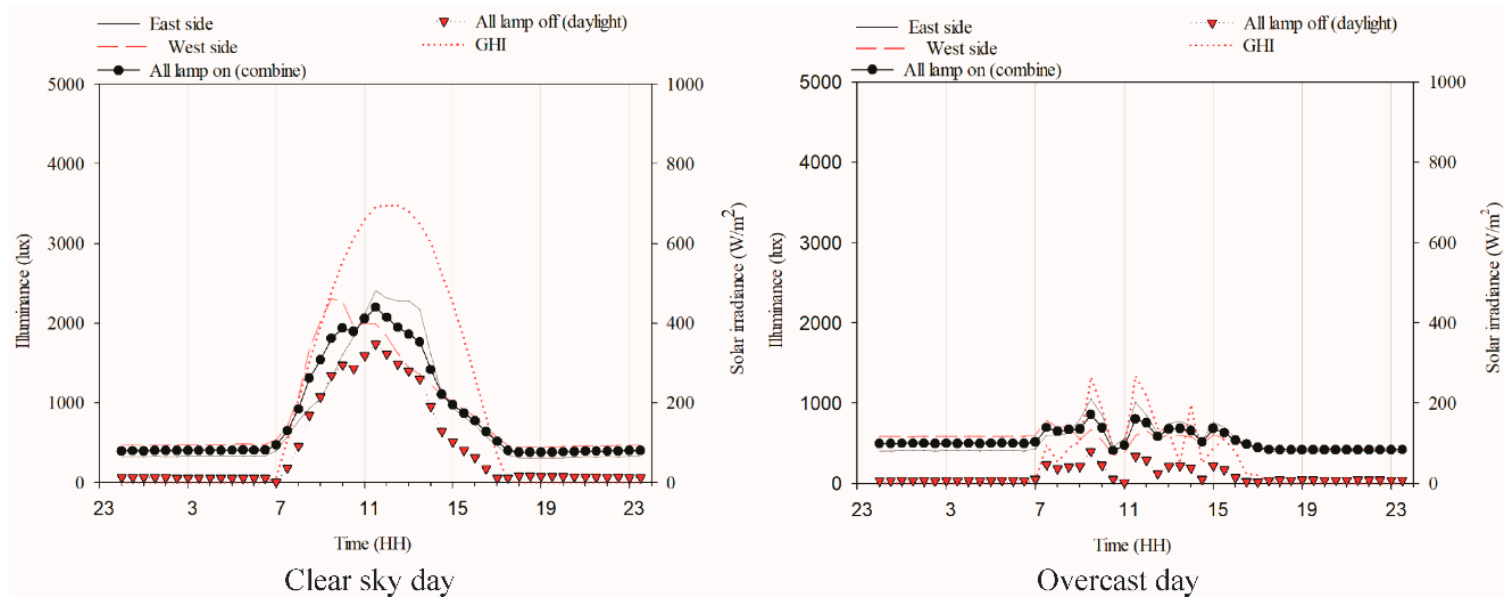

Figure 11. Indoor illuminance response to clear and overcast sky formation.

In Figure 11, the average indoor daylight illuminance was obtained by subtracting the illuminance of the lamp (460 lux) from the illuminance with all lamp switched on. On a clear sky day, the average indoor daylight illuminance was 870 lux and a maximum 
1740 lux. The average and maximum illuminance observed in the overcast day were 710 and 1340 lesser than those on a clear sky day. In both days, the average combined lamplight and daylight illuminance was approximately double that of the daylight.

A brief overview of lighting performance evaluation is presented to elaborate on the practical implication of the findings of Figure 11. Over the years, various standards, guidelines, and research metrics have set illuminance requirement for a series of visual task. The standard illuminance recommendation for visual task varies from one country to the other. For example, 500 lux is recommended for general office work by the Brazilian NBR 5413 [41], while the European EN 12464-1 standard, requires a minimum of 1500 lux, in electronic workshops, 300 lux in classrooms, and 300-500 lux in office space [42-44]. The IESNA in the United States recommend 300 lux in office space [45], and the CIBSE in the United Kingdom find 500 lux favorable in the same environment [46].

Meanwhile, Daylighting Autonomy (DA) and Useful Daylight illuminance (UDI) are the most commonly used metrics for evaluating daylighting performance in an interior space among researchers [47]. In this regard, DA is the percentage of annual daytime (occupied) hours that a given point is within a specified minimum daylight illuminance level. Although, no specific threshold illuminance is given for DA, recommended standards for a given visual task is often used; since most standards are based on minimum illuminance [48-51].

On the other hand, UDI is defined as the percentage of annual occupied time that a given point is within a specified range of daylight illuminance [52]. In most research studies, the range of daylight illuminance is given as 100-2000 lux [53-55]. Hence, UDI can be classified into three matric bins; daylighting below 100 lux is considered inadequate and requires electric lighting for visual comfort. Daylighting between 100 and 500 lux produces adequate light level but can be supplemented by electric lighting, while 500-2000 lux is desirable, tolerable and can result in discomfort with direct sun rays present [56].

The indoor daylight illuminance response to the various components of solar radiation was also analyzed. Similarly, the measured solar radiation during the indoor illuminance monitoring period was divided into 11 classes of $\hbar$ width. The corresponding indoor illuminance distribution in each of the classes was also obtained. Figure 12 shows the response of the office space illuminance to the various components of solar radiation.

Class 0 to 99.99 in Figure 12 represent combined electric light and daylight illuminance, while the other classes indicate daylight (sun present) illuminance of office space. Like Figures 7 and 8 , class 0 to $99.99 \mathrm{~W} / \mathrm{m}^{2}$ had the maximum occurrence considering DNI, DHI, and GHI distributions. In the above mentioned class, approximately $25 \%$ of the measured illuminance was observed in the presence of the sun. The daylighting found in the presence of the sun with all the lamps switched off, was higher than the combined illuminance by an average of 260 lux. Nevertheless, with all the lamps switched on and the sun present, the obtained daylight illuminance due to the variation of the DHI, was lesser than that of the combined illuminance by 618 lux. In the same scenario, the variation of DNI and GHI, however, led to a higher daylight illuminance by 230 and 100 lux, respectively. In the other classes, the indoor illuminance tends to increase as the various components of solar radiation increases, excluding the $\mathrm{L}_{\mathrm{d}}$ irradiance. Notwithstanding, a smaller DHI $\left(100-599.99 \mathrm{~W} / \mathrm{m}^{2}\right)$ range was observed to influence the daylight illuminance. It was also noted that as the DHI increases the frequency of occurrence decrease. The variation of DHI was found to result in a maximum indoor illuminance of 1420 lux, occurring $0.1 \%$ of the entire observation.

Contrarily, the maximum daylighting observed due to the variation of the DNI was 1540 lux with an occurrence frequency of $4 \%$. Meanwhile, $10 \%$ was the maximum occurrence frequency obtained in DNI distribution of the class of $800-899.99 \mathrm{~W} / \mathrm{m}^{2}$, and a resultant daylight illuminance of 1440 lux. In Figure 12, the combination of the DNI and DHI distribution was evidenced in the GHI profile. The GHI distribution maintained a reasonably constant occurrence frequency and broader irradiance $\left(100-899.99 \mathrm{~W} / \mathrm{m}^{2}\right)$. Among all the solar radiation components considered, a variation of the GHI of class 700 to 799.99 
resulted in the highest daylighting of 1650 lux; occurring $2 \%$ of the entire observation. The passive attribute of the $L_{d}$ irradiance was expected, given that $L_{d}$ radiation is a factor of the infrared spectra of solar radiation rather than the visible spectra. The daylighting response of the office space to the various solar radiation components is summarised in Table 4.
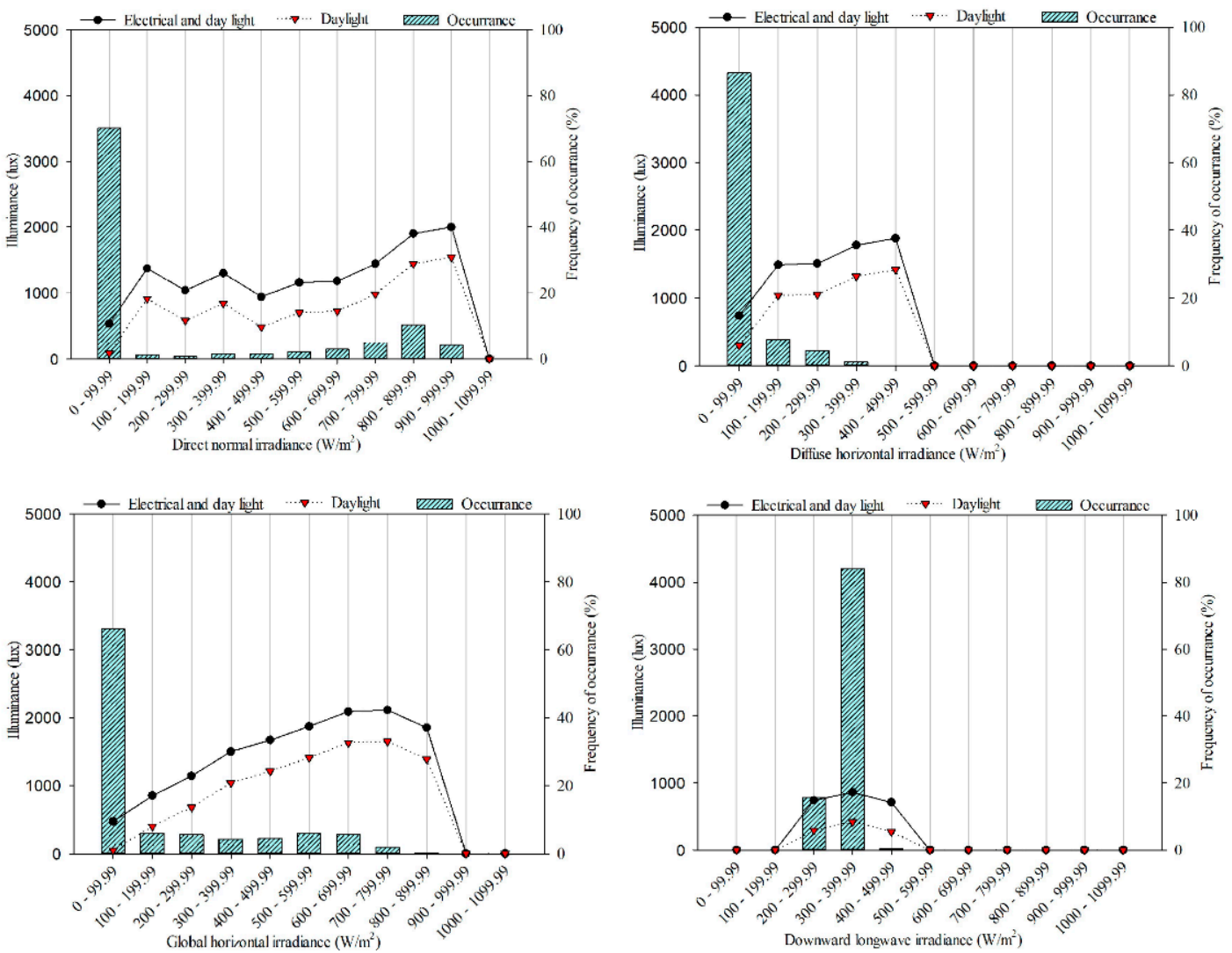

Figure 12. Indoor illuminance response of a passive solar building office space to various solar radiation components.

Table 4. Daylight illuminance response of a passive solar building office space to solar radiation components.

\begin{tabular}{cc}
\hline Solar Radiation Component & Illuminance Response $\left(\mathbf{l u x} / \hbar \mathbf{W} / \mathbf{m}^{\mathbf{2}}\right)$ \\
\hline DNI & 260 \\
DHI & 100 \\
GHI & 170 \\
L $_{\mathrm{d}}$ & 25 \\
\hline
\end{tabular}

The findings in Figure 12 and Table 4 agrees with the energy balance of the earth to the atmosphere system given in Section 2. DNI which was said to be non-attenuated radiation from the sun, was found to have the maximum influence on daylight illuminance. The vast impact of the DNI on the daylighting was not surprising given that before atmospheric interference, solar radiation is primarily in the visible region [12]. The absorbed solar radiation by the atmosphere is converted mainly into thermal energy. The proportion of thermal energy is represented by the $L_{d}$ irradiance, which had little or no influence on daylighting. In addition to absorption, visible radiation reaching the earth surface experiences scattering, and both atmospheric attenuations constitute DHI. Since scattering does not affect the energy or wavelength of solar radiation, a variation of DHI resulted in a significant daylight illuminance in Figure 12. However, DHI was found to have the least influence on daylighting among the DNI, DHI, and GHI as indicated in Table 4. The minimal daylighting response to DHI is due to the distance travelled (air mass) by the 
changing direction of the solar radiation. Moreover, the office space daylighting responded significantly to GHI, as the radiation possesses the attributes of DNI and DHI.

\section{Conclusions}

In this study, the thermal and daylight illuminance response of a passive solar building to selected components of solar radiation were observed and analyzed. Hence, direct normal irradiance (DNI), diffuse horizontal irradiance (DHI), global horizontal irradiance (GHI), and downward longwave $\left(\mathrm{L}_{\mathrm{d}}\right)$ irradiance were the selected solar radiation components considered and measured. Concurrently, the indoor air temperature and relative humidity which served as the thermal parameters of the office space were monitor. The thermal monitoring of the passive solar building also includes the outdoor air temperature and relative humidity. The office space illuminance comprises electric light and daylight; both parameters were monitored over a month. Although, the study was focused on the illuminance of the office space with all the lamp switched off and the sun present, which was referred to as daylighting in the study.

Thermally, DNI was found to have the least influence on the indoor thermal condition. The method adopted in measuring the thermal parameters, which assumed a practical scenario plays a significant role in the impact of the solar radiation component on the air temperature and relative humidity. However, DHI and GHI had the most influence on the indoor air temperature and relative humidity in the summer and winter seasons, respectively. Regarding daylight response, DNI was most dominant.

The findings of this study support the strategic locating of windows in a typical passive solar design. For optimum passive heating, larger north (south hemisphere) and south (north hemisphere) facing windows accompanied with proper shading device are recommended. By so doing, and as indicated by the results of this study, global horizontal radiation is admitted during the winter season, while diffuse horizontal radiation is experienced indoor in summer as direct sun rays are shaded by the shading devices. Admission of direct sun rays into the inner space of a building, in the case, through the north-facing clerestory windows can lead to significant about of daylighting within the UDI range. For a commercial building, energy consumed for electric lighting can be reduced by adopting passive solar design. On the downside, direct sun rays may result in visual discomfort associated with glare. Hence, south-facing windows are instead recommended for design to enhance indoor daylighting.

Author Contributions: All authors contributed significantly to this study. E.L.M. and O.K.O. identified and secured the passive solar building used in the study. The data acquisition system and installations of meteorological sensors were designed and installed by O.K.O. and E.L.M. O.K.O. and G.M. were responsible for periodic data collection. Data analysis was performed by O.K.O. and G.M. The manuscript was compiled by O.K.O. and technically reviewed by E.L.M. and G.M. All authors have read and agreed to the published version of the manuscript.

Funding: This research was funded by National Research Foundation grant number 116763 And The APC was funded by Govan Mbeki Research and Development Centre.

Institutional Review Board Statement: Not applicable.

Informed Consent Statement: Not applicable.

Data Availability Statement: New data were created or analyzed in this study. Data will be shared upon request and consideration of the authors.

Acknowledgments: The authors would like to express their gratitude to the following organization Eskom, Department of Science and Technology (PV spoke), Technology and Human Resources for Industry Programme funded by Department of Trade and Industry.

Conflicts of Interest: The authors declare no conflict of interest. 


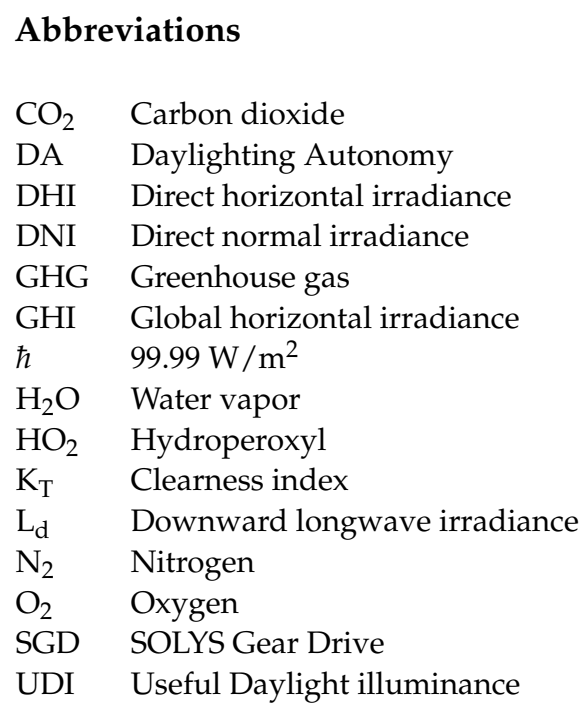

\section{References}

1. International Energy Agency. Energy Technology Perspectives 2016: Towards Sustainable Urban Energy Systems; International Energy Agency: Paris, France, 2016. Available online: www.iea.org (accessed on 7 July 2019).

2. Amasyali, K.; El-Gohary, N.M. A review of data-driven building energy consumption prediction studies. Renew. Sustain. Energy Rev. 2018, 81, 1192-1205. [CrossRef]

3. Molina-Solana, M.; Ros, M.; Ruiz, M.D.; Gomez-Romero, J.; Martin-Bautista, M.J. Data science for building energy management: A review. Renew. Sustain. Energy Rev. 2017, 70, 598-609. [CrossRef]

4. Priatman, J.; Soegihardjo, O.; Loekita, S. Towards Energy Efficient Facade Through Solar-powered Shading Device. Procedia-Soc. Behav. Sci. 2015, 179, 266-275. [CrossRef]

5. Wang, H.; Sun, F.; Wang, T.; Liu, W. Estimation of daily and monthly diffuse radiation from measurements of global solar radiation a case study across China. Renew. Energy 2018, 126, 226-241. [CrossRef]

6. Maleki, S.M.; Hizam, H.; Gomes, C. Estimation of Hourly, Daily and Monthly Global Solar Radiation on Inclined Surfaces: Models Re-Visited. Energies 2017, 10, 134. [CrossRef]

7. Rossi, T.J.; Escobedo, J.F.; dos Santos, C.M.; Rossi, L.R.; da Silva, M.B.P.; Pai, E.D. Global, diffuse and direct solar radiation of the infrared spectrum in Botucatu/SP/Brazil. Renew. Sustain. Energy Rev. 2018, 82, 448-459. [CrossRef]

8. Hinrichs, R.; Kleinbach, M. Energy: Its Use and the Environment, 5th ed.; BROOKS/COLE: New York, NY, USA, 2013.

9. Gutiérrez-Trashorras, A.J.; Villicaña-Ortiz, E.; Álvarez-Álvarez, E.; González-Caballín, J.M.; Xiberta-Bernat, J.; Suarez-López, M.J. Attenuation processes of solar radiation. Application to the quantification of direct and diffuse solar irradiances on horizontal surfaces in Mexico by means of an overall atmospheric transmittance. Renew. Sustain. Energy Rev. 2018, 81, 93-106. [CrossRef]

10. Coddington, O.; Lean, J.L.; Pilewskie, P.; Snow, M.; Lindholm, D. A solar irradiance climate data record. Bull. Am. Meteorol. Soc. 2016, 97, 1265-1282.

11. Chwieduk, D. Solar Energy in Buildings: Thermal Balance for Efficient Heating and Cooling; Elsevier: Amsterdam, The Netherlands, 2014

12. Nelson, V.C.; Starcher, K.L. Introduction to Renewable Energy; CRC Press: Boca Raton, FL, USA, 2015.

13. Mohammadi, K.; Shamshirband, S.; Petković, D.; Khorasanizadeh, H. Determining the most important variables for diffuse solar radiation prediction using adaptive neuro-fuzzy methodology; Case study: City of Kerman, Iran. Renew. Sustain. Energy Rev. 2016, 53, 1570-1579. [CrossRef]

14. Ruiz-Arias, J.A.; Gueymard, C.A. Worldwide inter-comparison of clear-sky solar radiation models: Consensus-based review of direct and global irradiance components simulated at the earth surface. Sol. Energy 2018, 168, 10-29. [CrossRef]

15. Gueymard, C.A. Cloud and albedo enhancement impacts on solar irradiance using high- frequency measurements from thermopile and photodiode radiometers. Part 1: Impacts on global horizontal irradiance. Sol. Energy 2017, 153, 755-765. [CrossRef]

16. South Africa Weather Service. Climate South Africa. 2017. Available online: ftp://ftp.weathersa.co.za (accessed on 1 January 2017).

17. Overen, O.K.; Meyer, E.L.; Makaka, G. Thermal, Economic and Environmental Analysis of a Low-Cost House in Alice, South Africa. Sustainability 2017, 9, 425.

18. Mousazadeh, H.; Keyhani, A.; Javadi, A.; Mobli, H.; Abrinia, K.; Sharifi, A. A review of principle and sun-tracking methods for maximizing solar systems output. Renew. Sustain. Energy Rev. 2009, 13, 1800-1818. [CrossRef]

19. Tang, W.; Yang, K.; He, J.; Qin, J. Quality control and estimation of global solar radiation in China. Sol. Energy 2010, 84, 466-475.

20. Kipp \& Zonen. Solar Monitoring Stations. 2012. Available online: http://www.kippzonen.com/Download (accessed on 24 May 2017). 
21. Campbell Scientific Inc. Solar Radiation Shields: For Temperature/Relative Humidity Sensors; Campbell Scientific Inc.: Utah, UT, USA, 2015. Available online: http:/ / campbellsci.com/solar-radiation-shields (accessed on 19 September 2018).

22. Jumo GmbH \& Co. Construction and Application of Platinum Temperature Sensors; Jumo GmbH \& Co.: Fulda, Germany, 2005. Available online: https:// www.jumo.net/attachments/JUMO/attachmentdownload?filename=t90.6000gb.pdf\&id=3008 (accessed on 19 November 2018).

23. Moser, Y.; Gijs, M.A.M. Miniaturised flexible temperature sensor. J. Microelectromech. Syst. 2007, 16, 1349-1354.

24. Campbell Scientific Inc. HMP60 Temperature and Relative Humidity Probe; Campbell Scientific Inc.: Utah, UT, USA, 2010.

25. Yamazoe, N.; Shimizu, Y. Humidity sensors: Principles and applications. Sens. Actuators 1986, 10, 379-398.

26. Rontronic Measurement Solutions. The Capacitive Humidity Sensor-How It Works \& Attributes of the Uncertainty Budget; Rontronic Measurement Solutions: New York, NY, USA, 2016. Available online: https:/ / www.rotronic.com/media/productattachments/ files/c/a/capacitive_humidity_sensor_final.pdf (accessed on 13 September 2018).

27. Biggs, W.W. Principles of Radiation Measurement; Lincoln: Dearborn, MI, USA, 2015. Available online: https://www.licor.com/ documents /liuswfuvtqn7e9loxaut (accessed on 13 September 2018).

28. Wang, C.; Tang, B.H.; Wu, H.; Tang, R.; Li, Z.L. Estimation of downwelling surface longwave radiation under heavy dust aerosol sky. Remote Sens. 2017, 9, 207. [CrossRef]

29. Teodoro, P.E.; Delgado, R.C.; Oliveira-junior, J.F.; Gois, G.; Sohn, F.T. Incoming Longwave Radiation Evaluation for the Legal Amazon Using HadRM3 and Geostatistic Theoretical Models. Floresta Ambient. 2018, 25, 1-8.

30. Stephens, G.L.; Wild, M.; Stackhouse, P.W.; L'Ecuyer, T.; Kato, S.; Henderson, D.S. The global character of the flux of downward longwave radiation. J. Clim. 2012, 25, 2329-2340. [CrossRef]

31. Santos, C.A.C.D.; Silva, B.B.D.; Rao, T.V.R.; Satyamurty, P.; Manzi, A.O. Downward Longwave Radiation Estimates For Clear-sky Condition Over Northeast Brazil. Rev. Bras. Meteorol. 2011, 26, 443-450.

32. Kreider, J.F.; Curtiss, P.S.; Rabl, A. Heating and Cooling of Buildings: Design for Efficiency, 2nd ed.; CRC Press: Denver, CO, USA, 2009.

33. Paulescu, M.; Paulescu, E.; Gravila, P.; Badescu, V. Weather Modeling and Forecasting of PV Systems Operation; Springer Science \& Business Media: London, UK, 2012.

34. Lai, C.S.; Li, X.; Lai, L.L.; McCulloch, M.D. Daily clearness index profiles and weather conditions studies for photovoltaic systems. Energy Procedia 2017, 142, 77-82. [CrossRef]

35. Ramgolam, Y.K.; Soyjaudah, K.M.S. Unveiling the solar resource potential for photovoltaic applications in Mauritius. Renew. Energy 2015, 77, 94-100. [CrossRef]

36. Li, D.H.W.; Lou, S. Review of solar irradiance and daylight illuminance modeling and sky classification. Renew. Energy 2018, 126, 445-453. [CrossRef]

37. Lou, S.; Li, D.H.W.; Lam, J.C. CIE Standard Sky classification by accessible climatic indices. Renew. Energy 2017, 113, 347-356. [CrossRef]

38. Zhandire, E. Solar resource classification in South Africa using a new index. J. Energy S. Afr. 2017, 28, 61-70. [CrossRef]

39. Yusuf, A. Characterization of Sky Conditions Using Clearness Index and Relative Sunshine Duration for Iseyin, Nigeria. Int. J. Phys. Sci. Res. 2017, 1, 53-60.

40. SABS. SANS 204:2011-South African National Standard: Energy Efficiency in Buildings; SABS Standards Division: Pretoria, South Africa, 2011; Volume 1.

41. Perin, A.N.; Bonamigo, D.F.; Ribeiro, M.D.Q.; Stock, R.A.; Remor, A.P.; Carvalho, D.D.; Steffani, J.A.; Bonamigo, E.L. Ergophthalmology in accounting offices: The computer vision syndrome (CVS). Rev. Bras. Oftalmol. 2017, 76, 144-149. [CrossRef]

42. Krüger, E.L.; Tamura, C.; Trento, T.W. Identifying relationships between daylight variables and human preferences in a climate chamber. Sci. Total Environ. 2018, 642, 1292-1302. [CrossRef]

43. de Bakker, C.; Aarts, M.; Kort, H.; Rosemann, A. The feasibility of highly granular lighting control in open-plan offices: Exploring the comfort and energy saving potential. Build. Environ. 2018, 142, 427-438. [CrossRef]

44. Fryc, I.; Bisegna, F.; Tabaka, P. Lighting of recreation grounds as a source of sky glow-The influence of luminaire type on this phenomenon. In Proceedings of the Environment and Electrical Engineering and 2017 IEEE Industrial and Commercial Power Systems Europe (EEEIC/I\&CPS Europe), Milan, Italy, 6-9 June 2017; pp. 1-4.

45. Choi, J.-H.; Loftness, V.; Aziz, A. Post-occupancy evaluation of 20 office buildings as basis for future IEQ standards and guidelines. Energy Build. 2012, 46, 167-175. [CrossRef]

46. Michael, A.; Gregoriou, S.; Kalogirou, S.A. Environmental assessment of an integrated adaptive system for the improvement of indoor visual comfort of existing buildings. Renew. Energy 2018, 115, 620-633. [CrossRef]

47. Chi, D.A.; Moreno, D.; Navarro, J. Correlating daylight availability metric with lighting, heating and cooling energy consumptions. Build. Environ. 2018, 132, 170-180. [CrossRef]

48. Mangkuto, R.A.; Rohmah, M.; Asri, A.D. Design optimization for window size, orientation, and wall reflectance with regard to various daylight metrics and lighting energy demand: A case study of buildings in the tropics. Appl. Energy 2016, 164, 211-219. [CrossRef]

49. Bian, Y.; Ma, Y. Analysis of daylight metrics of side-lit room in Canton, South China: A comparison between daylight autonomy and daylight factor. Energy Build. 2017, 138, 347-354. [CrossRef] 
50. Carlucci, S.; Causone, F.; de Rosa, F.; Pagliano, L. A review of indices for assessing visual comfort with a view to their use in optimization processes to support building integrated design. Renew. Sustain. Energy Rev. 2015, 47, 1016-1033. [CrossRef]

51. Pellegrino, A.; Cammarano, S.; Verso, V.R.M.L.; Corrado, V. Impact of daylighting on total energy use in offices of varying architectural features in Italy: Results from a parametric study. Build. Environ. 2017, 113, 151-162. [CrossRef]

52. Visitsak, S.; Beltran, L.; Sridaranon, N. The Daylight Performance of an Integrated Skylight and Shading Dome for the Tropics ISES Solar World Congr. 2017, 2017, 237-245. [CrossRef]

53. Yu, X.; Su, Y. Daylight availability assessment and its potential energy saving estimation-A literature review. Renew. Sustain. Energy Rev. 2015, 52, 494-503. [CrossRef]

54. Nabil, A.; Mardaljevic, J. Useful daylight illuminances: A replacement for daylight factors. Energy Build. 2006, 38, 905-913. [CrossRef]

55. Li, D.H.W.; Lou, S.; Ghaffarianhoseini, A.; Alshaibani, K.A.; Lam, J.C. A review of calculating procedures on daylight factor based metrics under various CIE Standard Skies and obstructed environments. Build. Environ. 2017, 112, 29-44. [CrossRef]

56. Al-Obaidi, K.M.; Ismail, M.A.; Rahman, A.M.A. Assessing the allowable daylight illuminance from skylights in single-storey buildings in Malaysia: A review. Int. J. Sustain. Build. Technol. Urban Dev. 2015, 6, 236-248. [CrossRef] 